\title{
Involvement of Cyclic Adenosine Monophosphate in the Interleukin 4 Inhibitory Effect on Interleukin 2-induced Lymphokine-activated Killer Generation
}

\author{
Jean-Yves Blay, Didier Branellec, Eric Robinet, Bernard Dugas, “ Francoise Gay, and Salem Chouaïb
}

Laboratoire d'Immunologie UA1156, Institut Gustave Roussy, 94805 Villejuif, France; and

*Institut Henri Beaufour, 91952 Les Ulis, France

\begin{abstract}
In previous studies, IL-4 has been reported to interfere with IL-2-driven generation of lymphokine-activated killer (LAK) activity. In this investigation, we have demonstrated that IL-4 inhibited the IL-2-induced differentiation of large granular lymphocytes (LGL) into LAK effectors by a mechanism involving, at least in part, an increase in LGL intracellular cAMP levels. In contrast, with its capacity to induce cAMP accumulation in resting $L G L, I L-4$ had a very negligible effect on LAK activity induction, and CAMP levels increase in LGL that had been preincubated with IL-2. Furthermore, the inhibitory effect of $\mathrm{IL}-\mathbf{4}$ on $\mathrm{LAK}$ activity generation also correlated with a marked decrease in $\mathrm{N}$-CBZ-L-lysine thiobenzylester esterase activity, with an inhibition of tumor necrosis factor (TNF) mRNA expression and TNF production by IL-2-stimulated LGL. These results strongly suggest that complex signaling processes could be ascribed to the dual activities of cytokines and their interplay in LAK promotion. (J. Clin. Invest. 1990. 85:1909-1913.) cyclic adenosine monophosphate • cytokine interplay $\bullet$ lymphokine-activated killer
\end{abstract}

\section{Introduction}

Cytokines form a network of regulatory signals and several lines of evidence suggest the existence of a considerable overlap in their activities which leads to unexpected patterns of synergism or antagonism. First reported as a B cell stimulatory factor, interleukin 4 (IL-4) has been found to exhibit a wide range of cell activation properties on various types of immunocompetent cells in a species specific manner (1-4). IL-4 is reported to exert both positive and negative regulatory effects on the generation of non-MHC-restricted cytotoxicity (5-10). It has been demonstrated that addition of recombinant human IL-4 strongly inhibits the interleukin 2 (IL-2)-mediated proliferation and differentiation of human resting peripheral blood lymphocytes (PBL) into lymphokine-activated killer (LAK) ${ }^{1}$ effectors $(5,9,10)$. However, recent reports suggest that the immunoregulatory properties of IL-4 on non-MHC-restricted

Address reprint requests to Dr. Chouaib, Laboratoire d'Immunolgie, CNRS UA1156, Institut Gustave Roussy, Rue Camille-Desmoulins, 94805 Villejuif Cedex, France.

Received for publication 25 August 1989 and in revised form 6 February 1990.

1. Abbreviations used in this paper: BLT-E, N-CBZ-L-lysine thiobenzylester esterase; LAK, lymphokine-activated killers; LGL, large granular lymphocytes; NK, natural killer; TNF, tumor necrosis factor.

J. Clin. Invest.

(c) The American Society for Clinical Investigation, Inc.

0021-9738/90/06/1909/05 $\$ 2.00$

Volume 85, June 1990, 1909-1913 cytotoxicity are dependent on the cell activation state $(5,9)$. While having no effect alone on non-MHC-restricted lytic capacity of resting human PBL $(5,7-10)$, IL-4 by itself is able to selectively enhance LAK activity of IL-2-prestimulated PBL and large granular lymphocytes (LGL) $(9,10)$. The precise molecular mechanism underlying the antagonistic effect of IL-2 and IL-4 has not yet been established. Moreover, the signal transduction pathway of human IL-4 is not yet known. The inhibitory properties of cyclic AMP (cAMP) and cAMPinducing agents for several immune responses $(11-14)$ such as IL-2-induced cell activation have been well documented (15, 16). Although there are several important questions regarding the role of $N$-CBZ-L-lysine thiobenzylester esterase (BLT-E) in cell-mediated cytotoxicity $(17,18)$, there is a prevailing view that an elevated BLT-E activity seems to correlate with cytotoxic activity $(19,20)$. We questioned whether or not the IL-4 inhibitory effect on IL-2-driven LGL differentiation and the subsequent acquisition of their lytic potential involves the cAMP pathway. In this report, we demonstrate that heightened cAMP levels resulting from IL-2/IL-4 costimulation of LGL interfere with the transmission of the IL-2 signal leading to LAK promotion by inhibiting the serine esterase increase and TNF mRNA expression in LGL.

\section{Methods}

Cell preparation. Fresh human large granular lymphocytes were purified as previously described (21). Briefly, human peripheral blood mononuclear cells were obtained by leukapheresis of normal blood donors (Blood Bank, Hôpital St-Louis, Paris) and were separated on Ficoll/Hypaque. After a 1 -h adherence to plastic at $37^{\circ} \mathrm{C}$ in $5 \% \mathrm{CO}_{2}$, nonadherent cells were loaded over a discontinuous Percoll gradient (Pharmacia Fine Chemicals, Uppsala, Sweden) and centrifuged $30 \mathrm{~min}$ at $500 \mathrm{~g}$. LGL were recovered from the low-density fraction. The resulting LGL preparations ( $5 \%$ of the initial peripheral blood mononuclear cell population) contained $>90 \%$ LGL. Immunofluorescence analysis of CD14 (a monocyte/granulocyte-specific antigen) expression on LGL showed $<0.5 \%$ of positive cells, indicating the absence of contaminating monocytes.

LAK activation and cytotoxicity assay. LGL $\left(10^{6} / \mathrm{ml}\right)$ were cultured for $3 \mathrm{~d}$ in complete medium (RPMI $1640 / 10 \%$ normal human serum) in presence of the indicated lymphokines, dibutyryl-cAMP (Sigma Chemical Co., Strasbourg, France) or forskolin (Sigma Chemical Co.). The cells were then harvested, washed three times, and used as effector cells after serial dilutions in complete medium in round bottom microtiter plate. The natural killer (NK)-resistant B lymphoblastoid cell line Daudi, the myelomonocytic cell line U937, and the epidermoid carcinoma cell line ORL were used as targets. Target cells $\left(2 \times 10^{6}\right.$ cells in $0.2 \mathrm{ml})$ were labeled with $200 \mu \mathrm{Ci} \mathrm{Na} 2 \mathrm{CrO}(5 \mathrm{mCi} / \mathrm{ml}$, Commissariat à l'énergie atomique, Saclay, France) for $1 \mathrm{~h}$ at $37^{\circ} \mathrm{C}$ followed by three washes. $0.1 \mathrm{ml}$ of a suspension of ${ }^{51} \mathrm{Cr}$-labeled target cells $\left(10^{5}\right.$ cells $/ \mathrm{ml}$ ) were dispended into the wells containing dilutions of effector cells. After a 4-h incubation at $37^{\circ} \mathrm{C}$, the supernatants were harvested using a harvesting device (Skatron, Lier, Norway). Spontaneous release 
was determined by incubating target cells with medium alone. Maximum release was determined by adding $100 \mu \mathrm{l}$ of $\mathrm{HCl} 1 \mathrm{~N}$ to $100 \mu \mathrm{l}$ of the target suspension. Percent of specific lysis was calculated as follows: (experimental ${ }^{51} \mathrm{Cr}$ release [cpm] - spontaneous ${ }^{51} \mathrm{Cr}$ release)/(maximum ${ }^{51} \mathrm{Cr}$ release $[\mathrm{cpm}]-$ spontaneous ${ }^{51} \mathrm{Cr}$ release) $\times 100$. Data are reported as the number of lytic units per $10^{6}$ cells as previously described (21). A lytic unit is the reciprocal of the number of effector cells that causes $30 \%$ lysis of $10^{-4}{ }^{51} \mathrm{Cr}$-labeled target cells.

$\left[{ }^{3} \mathrm{H}\right]$ Thymidine incorporation assay. LGL $\left(1 \times 10^{6}\right.$ cells $\left./ \mathrm{ml}\right)$ resuspended in RPMI 1640 supplemented with $10 \%$ normal human serum were distributed in flat bottomed microtiter plates (Costar Data Packaging Corp., Cambridge, MA) in the presence or the absence of the indicated concentration of lymphokines. After a 72-h incubation at $37^{\circ} \mathrm{C}$ in $5 \% \mathrm{CO}_{2}$ humidified atmosphere, the culture were pulse-labeled $12 \mathrm{~h}$ with $1 \mu \mathrm{Ci}$ of $\left[{ }^{3} \mathrm{H}\right]$ thymidine (TdR) (TMM 48B, $5 \mathrm{mCi} /$ mmol, CEA) and harvested onto filter paper with a harvesting apparatus (Skatron). Thymidine incorporation was then measured in a scintillation counter (LKB Produkter, Bromma, Sweden) (22). The results are expressed as mean incorporation of triplicate wells.

Measurement of intracellular cAMP. LGL were incubated 10 or 30 min in complete medium in presence of the indicated lymphokines or forskolin, then centrifuged $5 \mathrm{~min}$ at $2,000 \mathrm{rpm}$, resuspended in a lysis buffer (sodium acetate $50 \mathrm{mM}$ ) and placed $5 \mathrm{~min}$ in liquid nitrogen and 2 min in a boiling water bath. CAMP was measured in cell lysates using a cAMP kit assay (TRK432, Amersham, les Ulis, France) according to the kit procedure. Briefly, samples and standards were incubated $3 \mathrm{~h}$ at $4^{\circ} \mathrm{C}$ in presence of tritiated cAMP before addition of charcoal, which binds CAMP with a high affinity. Charcoal and supernatant were separated by centrifugation $5 \mathrm{~min}$ at $2000 \mathrm{~g}$. Supernatants containing nonadsorbed cAMP were collected and tritiated cAMP was measured in triplicates in a scintillation counter (LKB Produkter).

$B L T-E$ assay. After $3 \mathrm{~d}$ of incubation in complete medium with or without IL-2 and/or IL-4, LGL were lysed by incubating $10^{7}$ cells $/ \mathrm{ml}$ in PBS containing $0.5 \%$ Nonidet P40 (Sigma Chemical Co.) at $4^{\circ} \mathrm{C}$ for $30 \mathrm{~min}$. Serine esterase activity in $50 \mu \mathrm{l}$ of cell lysates was determined by measuring the clivage of $N$-CBZ-L-Lys-thiobenzyl ester (BLT, Sigma Chemical Co.) as reported (17). Each assay was performed in triplicate. The absorbance at $420 \mathrm{~nm}$ was measured after $2 \mathrm{~h}$ at room temperature using a microplate ELISA reader (Titertek Multiscan, MC, Helsinki, Finland). In all cases, the OD of a blank well containing sample but lacking BLT was substracted from that with substrate. An absorbance of $1.0 \mathrm{U}$ of O.D. after $2 \mathrm{~h}$ was defined as $1 \mathrm{U}$ of BLT-E activity.

Evaluation of TNF- $\alpha$ mRNA expression. LGL $\left(10^{6}\right.$ cells $\left./ \mathrm{ml}\right)$ were incubated for $6 \mathrm{~h}$ in complete medium in the presence of the indicated lymphokines. Cytoplasmic RNA were obtained according to the procedure described (23). Dilutions of denatured RNA of $2 \times 10^{6}$ cells were applied with suction to nylon sheet using a 96-well Minifold apparatus. After an 18 -h hybridization at $65^{\circ} \mathrm{C}$ with either an $\left[\alpha{ }^{32} \mathrm{P}\right]-$ dCTP (Amersham)-labeled TNF DNA probe or a $\beta$-actin DNA probe, nylon sheets were washed $30 \mathrm{~min}$ in $2 \times \mathrm{SSC}$ and $0.2 \times \mathrm{SSC}$ at $65^{\circ} \mathrm{C}$ and then exposed to $\mathrm{x}$-ray films at $-70^{\circ} \mathrm{C}$ for $3 \mathrm{~d}$ as described (24). TNF- $\alpha$ and $\beta$-actin DNA probes were labeled using the Multiprime DNA labeling systems (RPN1601Y, Amersham) according to the kit procedure.

Measurement of immunoreactive TNF- $\alpha$. LGL $\left(10^{6} \mathrm{cells} / \mathrm{ml}\right)$ were incubated for $24 \mathrm{~h}$ in complete medium in presence of the indicated lymphokines. Supernatants were then collected and stored frozen at $-20^{\circ} \mathrm{C}$ until the assay. Quantification of immunoreactive TNF- $\alpha$ was performed using an immunoradiometric method (TNF $\alpha$-IRMA, Medgenix Diagnostics, Fleurus, Belgium) according to the kit procedure. The TNF- $\alpha$ IRMA does not cross-react with TNF- $\beta$.

Sources of lymphokines. Highly purified recombinant human IL-2 (specific activity $=23.3 \times 10^{6} \mathrm{U} / \mathrm{mg}$ of protein) used in this study was kindly provided by Sanofi (Bio Recherches, Labege, France). Highly purified recombinant human IL-4 (specific activity $=10^{7} \mathrm{U} / \mathrm{mg}$ of protein) was kindly provided by Dr. J. Banchereau (Unicet, Dardilly, France).

\section{Results}

IL-4 induces an increase of intracellular CAMP in IL-2 activated $L G L$. Because cAMP has been reported as a negative signal for several immune responses (11-14), we investigated its possible involvement in the inhibitory effect of IL-4 on the IL-2-driven LAK generation. Intracellular cAMP was measured in LGL after a 10 - or 30-min stimulation with IL-2 in the presence or absence of IL-4. Results presented in Table I indicate that costimulation of LGL with $\mathrm{IL}-2(2 \mathrm{ng} / \mathrm{ml})$ and an inhibitory concentration of IL-4 $(100 \mathrm{U} / \mathrm{ml})$ for LAK generation resulted in a marked increase of intracellular cAMP (fourfold) compared with the basal level. Incubation of LGL with the same concentrations of IL-4 alone leads to a less important increase of cAMP levels (2.5-fold) compared with what is observed with the combination of both cytokines whereas IL-2 alone did not significantly affect cAMP level. Our results indicate that cAMP increased to a maximal level

Table I. IL-4 Increases CAMP Levels in LGL

\begin{tabular}{|c|c|c|c|c|c|c|c|}
\hline \multicolumn{2}{|c|}{ Culture conditions } & \multicolumn{2}{|c|}{ cAMP level } & \multicolumn{3}{|c|}{ Lytic units } & \multirow{2}{*}{$\begin{array}{l}\text { HTdR } \\
\text { uptake }\end{array}$} \\
\hline IL-2 & IL-4 & $10 \mathrm{~min}$ & $30 \mathrm{~min}$ & Daudi & U937 & ORL & \\
\hline$n g / m l$ & $U / m l$ & \multicolumn{2}{|c|}{ fmol $/ 10^{\circ}$ cells } & & & & $c p m$ \\
\hline 0 & 0 & ND & $4,200 \pm 110$ & 4 & 3 & $<1$ & 2,700 \\
\hline 2 & 0 & $5,900 \pm 450$ & $2,800 \pm 140$ & 195 & 133 & 35 & 53,000 \\
\hline 0 & 0.1 & $5,500 \pm 360$ & $5,750 \pm 420$ & 4 & 2 & $<1$ & 3,000 \\
\hline 0 & 1 & $8,000 \pm 220$ & $7,500 \pm 530$ & 3 & 2 & $<1$ & 2,900 \\
\hline 0 & 10 & $8,900 \pm 70$ & $7,500 \pm 130$ & 4 & 3 & $<1$ & 2,100 \\
\hline 0 & 100 & $9,200 \pm 360$ & $11,500 \pm 470$ & 9 & 5 & $<1$ & 2,500 \\
\hline 2 & 0.1 & $6,300 \pm 75$ & $6,250 \pm 230$ & 187 & 142 & ND & ND \\
\hline 2 & 1 & $9,500 \pm 430$ & $11,500 \pm 460$ & 133 & 115 & 29 & 27,000 \\
\hline 2 & 10 & $14,500 \pm 370$ & $17,500 \pm 90$ & 65 & 42 & ND & 17,000 \\
\hline 2 & 100 & $15,250 \pm 280$ & $19,000 \pm 170$ & 6 & 2 & 2 & 12,000 \\
\hline 2 & $0+$ FK$^{*}$ & $24,000 \pm 480$ & $12,000 \pm 230$ & $<1$ & $<1$ & $<1$ & 1,500 \\
\hline
\end{tabular}

cAMP levels in purified LGL were measured after 10 and $30 \mathrm{~min}$ of incubation in the presence of the indicated lymphokines. In parallel, LGL of the same donor were incubated $3 \mathrm{~d}$ in the same conditions and then tested for proliferation and cytotoxic activity. Data shown here are representative of five different experiments. ${ }^{*} \mathrm{FK}$, forskolin $\left(10^{-4} \mathrm{M}\right)$. 
after 10 and $30 \mathrm{~min}$ of incubation with both lymphokines then decreased after 60 and $120 \mathrm{~min}$ of incubation (data not shown). It is also shown in Table I that the IL-2/IL-4-mediated increase in cAMP was clearly associated with an inhibition of both LGL proliferation and their capacity to differentiate into LAK effectors as revealed by the killing of the NKresistant targets (Daudi, U937, ORL). When forskolin $\left(10^{-4}\right.$ M) was added at the initiation of LGL culture, a significant increase of intracellular cAMP occurred. Such an increase also resulted in a marked inhibition of LAK activity and LGL proliferation. To examine whether cAMP increases are directly involved in the IL-4 inhibitory effect, experiments were performed to test cAMP levels in LGL treated with IL-4 after IL-2 prestimulation. Table II depicts the results observed when LGL were simultaneously treated with IL-2 $(2 \mathrm{ng} / \mathrm{ml})$ in the presence of IL-4 $(100 \mathrm{U} / \mathrm{ml})$ or preincubated $3 \mathrm{~d}$ in the presence of IL-2 and then treated with IL-4. It is shown in this table that IL-4 induced an inhibition of LAK activity and an increase of cAMP accumulation within resting LGL. In contrast, addition of IL-4 $(100 \mathrm{U} / \mathrm{ml})$ on IL-2-prestimulated LGL failed to inhibit LAK activity generation and did not affect the intracellular levels of cAMP. This indicates a differential effect of IL-4 on the cAMP levels increase by resting and IL-2-prestimulated LGL.

IL-4 inhibits BLT-E activity in LAK effectors. To gain more insight into the inhibitory effect of IL-4 on IL-2-driven LAK generation, we asked whether this lymphokine could affect the serine esterase activity in LGL, such as the BLT-E, suggested to be a marker of NK and CTL lytic capacity (17, 18). We investigated then the effect of IL-4 on the intracellular BLT-E activity in IL-2-activated LGL. Results presented in Fig. 1 indicate that the acquisition of the lytic competence of LAK effectors towards Daudi target was accompanied by a 2.5-fold increase in the intracellular BLT-E activity. Addition of inhibitory concentrations of IL-4 at the initiation of the culture markedly reduced the intracellular content of BLT-E in a dose-dependent manner. This decrease directly correlated

Table II. cAMP Levels in Resting and IL-2-prestimulated LGL after Stimulation with $I L-4$

\begin{tabular}{|c|c|c|c|c|c|c|}
\hline \multirow[b]{2}{*}{ Cells } & \multicolumn{3}{|c|}{ Culture conditions } & \multicolumn{2}{|c|}{ cAMP levels } & \multirow{2}{*}{$\begin{array}{l}\text { Lytic } \\
\text { units }\end{array}$} \\
\hline & IL-2 & IL-4 & FK* $^{*}$ & $10 \mathrm{~min}$ & $30 \mathrm{~min}$ & \\
\hline & $n g / m l$ & $U / m l$ & \multicolumn{4}{|c|}{ fmol $/ 10^{6}$ cells } \\
\hline Resting & 0 & 0 & 0 & NT & $2,200 \pm 130$ & 2 \\
\hline \multirow[t]{4}{*}{ LGL } & 0 & $\mathbf{0}$ & $+^{\ddagger}$ & $14,500 \pm 110$ & $9,800 \pm 230$ & NT \\
\hline & 2 & 0 & 0 & $3,700 \pm 80$ & $1,400 \pm 90$ & 84 \\
\hline & $\mathbf{0}$ & 100 & 0 & $3,900 \pm 120$ & $5,100 \pm 80$ & 8 \\
\hline & 2 & 100 & 0 & $5,000 \pm 150$ & $7,600 \pm 140$ & 16 \\
\hline Preactivated & 0 & 0 & $\mathbf{0}$ & NT & $1,400 \pm 25$ & 8 \\
\hline \multirow[t]{4}{*}{ LGL } & 0 & 0 & + & $11,500 \pm 240$ & $8,700 \pm 180$ & NT \\
\hline & 2 & 0 & 0 & $1,300 \pm 100$ & $1,250 \pm 230$ & 192 \\
\hline & 0 & 100 & 0 & $1,200 \pm 50$ & $1,490 \pm 120$ & 48 \\
\hline & 2 & 100 & 0 & $1,350 \pm 200$ & $1,480 \pm 130$ & 166 \\
\hline
\end{tabular}

cAMP levels were measured in resting and IL-2-preactivated (3 d) LGL after a 10 - and 30-min stimulation by the indicated cytokines. LGL were incubated $3 \mathrm{~d}$ in the same conditions and tested for LAK activity against Daudi cell line. Cytotoxic activity is expressed in lytic units. ${ }^{*} \mathrm{FK}$, forskolin $\left(10^{-4} \mathrm{M}\right) .^{\ddagger}$ In the presence of forskolin.

\section{BLT-E ACTIVITY}

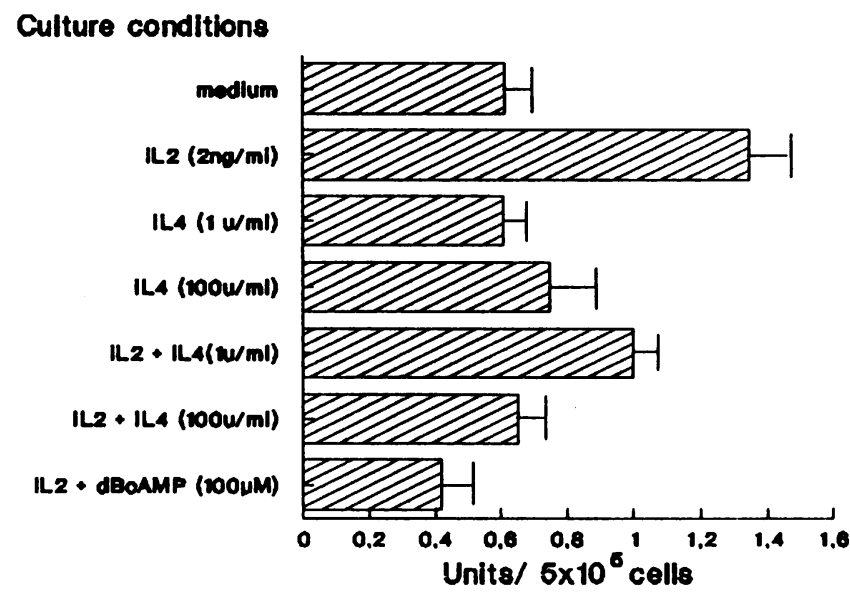

\section{LAK ACTIVITY}

Culture conditions

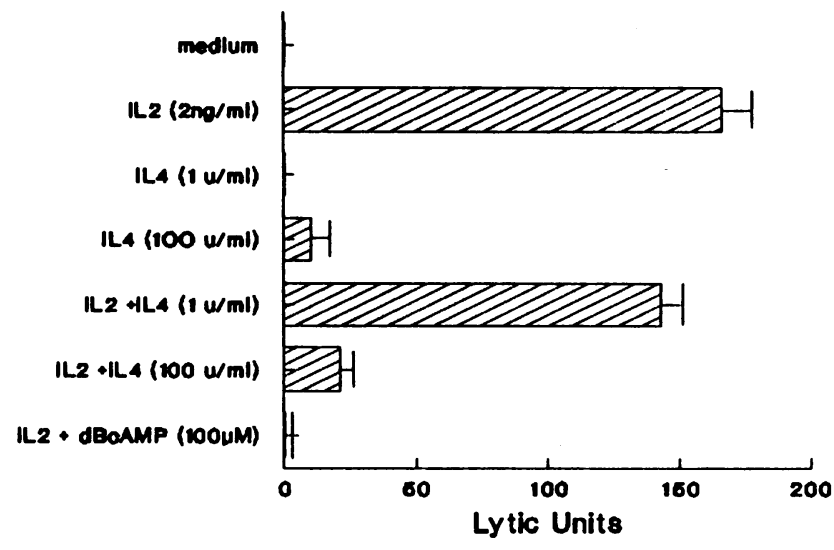

Figure 1. Effect of IL-4 on BLT-E activity in IL-2-activated LGL. (Top) Lysate of $5 \times 10^{5} \mathrm{LGL}$ stimulated by the indicated lymphokines were tested in triplicates for BLT-E activity as indicated in Methods. (Bottom) LAK activity was measured against Daudi target in a 4-h ${ }^{51} \mathrm{Cr}$-release assay. Bars indicate the mean and SD of a representative experiment out of five.

with the level of cytotoxicity measured against Daudi target. Addition of dBcAMP $\left(10^{-4} \mathrm{M}\right)$ at the initiation of the culture similarly resulted in a significant decrease of BLT-E activity, concomitantly with an inhibition of LAK cytotoxic function of IL-2-activated LGL.

IL-4 inhibits TNF MRNA expression and TNF production by $I L-2$ activated $L G L$. IL-2 has been shown to induce TNF mRNA expression in LGL and TNF biological activity release in the culture medium, a phenomenon partially associated with acquisition of LAK activity by $\operatorname{LGL}(12,25)$. To examine whether the inhibitory effect of IL-4 on IL-2-induced LAK generation interferes with TNF release, we have first investigated the effect of IL-4 on TNF mRNA expression in IL-2-activated LGL. Dot blot hybridization using a cDNA TNF probe (Fig. 2) shows that addition of a concentration of IL-4 (100 $\mathrm{U} / \mathrm{ml}$ ) able to inhibit LAK generation strongly reduces TNF mRNA expression in IL-2-stimulated LGL. It is also shown in this figure that addition of $\operatorname{dBcAMP}\left(10^{-4} \mathrm{M}\right)$ also resulted in a marked inhibition of TNF mRNA expression in IL-2-stimu- 
lated LGL. Rehybridization of the same filter with a beta actin cDNA probe confirmed that all samples contained similar amounts of RNA (not shown). To further investigate the effect of IL-4 on TNF release by IL-2-activated LGL, we measured TNF in LGL supernatants after $24 \mathrm{~h}$ of incubation in the same conditions (Fig. 2). Data presented here show that IL-2 induces the production of detectable concentrations of TNF by LGL $(190 \mathrm{pg} / \mathrm{ml})$. In contrast, when a concentration of IL-4 (100 $\mathrm{U} / \mathrm{ml}$ ) able to increase intracellular cAMP was added at the beginning of the LGL culture in the presence of IL-2, an important decrease (88\% inhibition) of TNF production was observed $(22 \mathrm{pg} / \mathrm{ml})$. Addition of $\operatorname{dBcAMP}\left(10^{-4} \mathrm{M}\right)$ at the initiation of the culture also consistently inhibited ( $92 \%$ inhibition) TNF production ( $15 \mathrm{pg} / \mathrm{ml})$ by IL-2-stimulated LGL as compared to the control culture.

\section{Discussion}

The data presented in this report confirm earlier observations showing that IL-4 inhibits the capacity of human LGL to be activated by IL-2 and to differentiate into LAK effectors (5, 7-9). Although some reports suggested that IL-4 acts at the induction phase of cytolytic activity $(8,9)$, no conclusive explanation has been proposed to account for this inhibition. In the current study, we attempted to gain more detailed understanding of the mechanism by which IL -4 downregulates the capacity of IL-2 to generate LAK effectors.

Our findings clearly indicate that, when IL-4 is used in costimulation with IL-2, the marked suppression on LAK activity occurs concomitantly with a significant increase in intracellular cAMP levels in LGL. Our results support the hy-

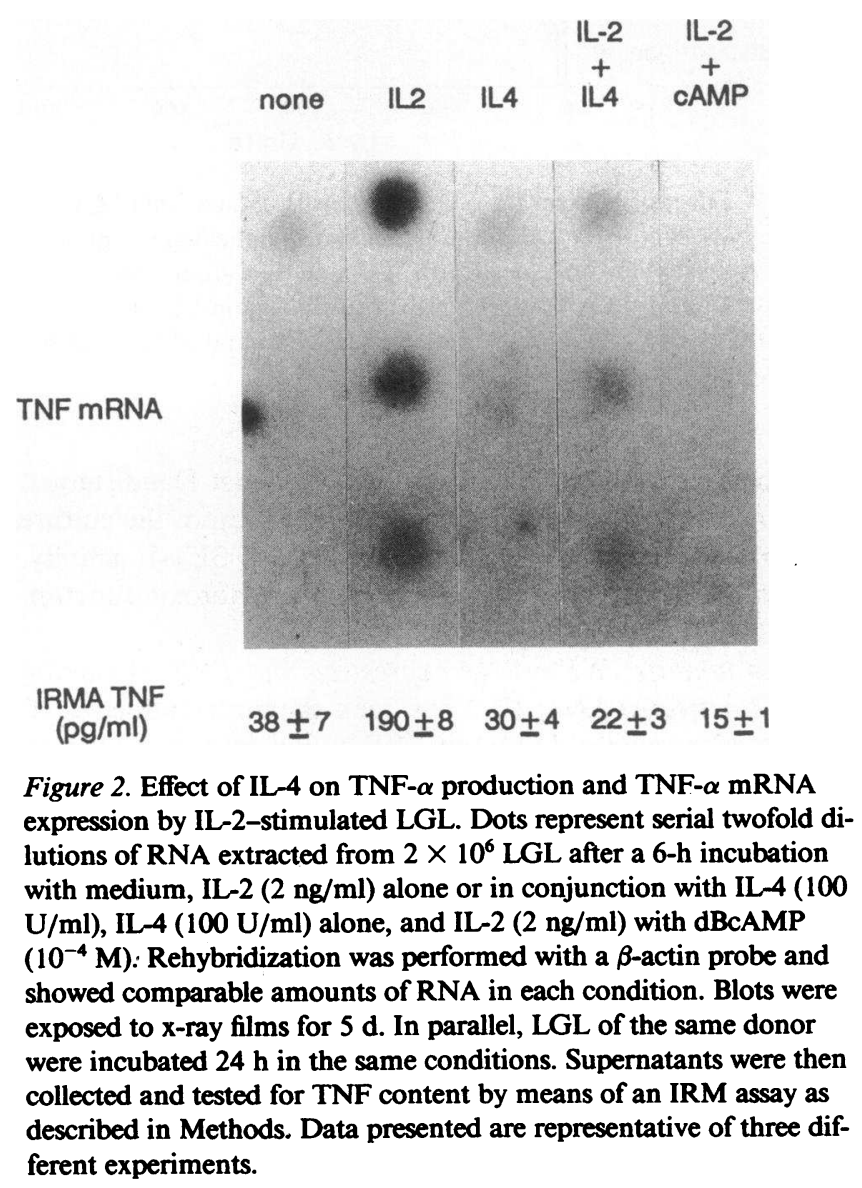

pothesis that cAMP could be involved in signal transduction of human IL-4 and provide additional insights on the inhibitory function of the cAMP pathway on the amplification and effector phase of the immune effector function (11-14). It has recently been shown that IL-4 alone is able to trigger the differentiation of IL-2-prestimulated PBL into LAK effectors. In addition, our results indicate that IL-4 induces a nonsignificant increase of intracellular cAMP in IL-2-prestimulated LGL, that already display LAK activity. These observations provide further support of the association of cAMP elevation with the inhibitory effect of IL-4 on LAK generation by resting LGL and also point to the possible existence of distinct controls of transduction pathways according to the activation state of the cells.

It is well established that the elevation of intracellular cAMP generally causes the activation of a cAMP-dependent protein kinase A (13). This enzyme phosphorylates substrate proteins that may regulate the initiation process including activation of a receptor coupling signal transduction system and gene transcription. It has also been reported that elevation of cAMP levels antagonizes the IL-2-stimulated T cell progression (16). It is conceivable therefore that the suppressive influence of CAMP through a cAMP-dependent protein kinase interferes with some intermediate biochemical events after IL-2 receptor triggering on LGL. For instance, cAMP may affect the protein kinase $C$ activation and phosphorylation of some proteins associated with the development of functional expression by LAK effectors. It has been recently reported that down-modulation of protein kinase $C$ correlates with a loss of LAK activity (26). Furthermore, it has been shown that BSF-1 interaction with its receptor activates a membrane associated protein kinase other than protein kinase $C$ in resting $B$ cells (27). In this respect, the elucidation of the mechanisms by which IL-4 interferes with the adenylate cyclase system and the subsequent protein kinase stimulation could be of considerable importance.

Multiple putative roles have been advanced for serine esterases in cell mediated cytotoxicity $(17,18)$. Our results indicate that IL-4 interferes with the IL-2-induced BLT-E activity in LGL. A similar inhibition of BLT-E activity also occured when LGL cultures were treated with $\mathrm{DBcAMP}$ further suggesting an involvement of this cyclic nucleotide in the IL-4mediated inhibition of BLT-E activity. It should be stressed, however, that the inhibitory effect of IL-4 on LAK activity was more pronounced than on BLT-E activity. This is consistent with a lack of association between the intensity of LGL cytotoxic function and the BLT-E enzymatic activity and in agreement with the concept that the killing pathway and the BLT-E induction may be under a distinct control. Our findings also indicate that IL-4 interferes with BLT-E activity in LGL but does not affect the basal cellular content of the enzyme in unstimulated LGL indicating that IL-4 mainly affects the IL-2-dependent part of the lytic potential of IL-2-activated LGL. These results are in contrast with a previous report in the murine model (8) indicating that stimulation of PBL with the combination of IL- 2 and IL-4 resulted in both marked increase of LAK cytotoxic capacity and BLT-E activity (8).

Our studies also show another site of IL-4 action on LAK generation by its capacity to inhibit TNF gene expression and TNF production by IL-2-stimulated LGL. This confirms previous observations suggesting that LAK development involves, at least in part, TNF production $(22,25)$. It should be noted 
that $\mathrm{dBcAMP}$ and other cAMP inducing agents such as forskolin (not shown) also inhibited both TNF mRNA expression and TNF production by IL-2-activated LGL, confirming the involvement of cAMP in the IL-4-induced inhibition of LGL function. Although a recent report has demonstrated that human IL- 4 impaired TNF- $\alpha$ gene expression by monocytes (28), the inhibitory effect of IL-4 on the IL-2-induced TNF production under our experimental conditions is not due to contaminating monocytes in LGL preparation since Leu M3positive cells represented $<0.5 \%$ of LGL preparation (not shown).

In conclusion, our data suggest that IL-4, presumably through the CAMP pathway, is able to affect gene transcription or posttranscriptional events involved in the acquisition of the LAK lytic competence by the LGL. Further studies will be required to clarify this issue. The understanding of IL-4 signaling pathway and of the cytokines induced cross-talk between cellular signaling pathways during LAK differentiation are of considerable importance and may help to more precisely delineate the complex interplay of cytokines in cell-mediated cytotoxicity and their use in combination in antitumor therapy.

\section{Acknowledgments}

The authors wish to thank Dr. A. Bernard and M. C. Dockelar for valuable suggestions and for reading the manuscript, Dr. A. Shaw for the TNF- $\alpha$ probe, and Dr. P. Henkart for helpful advice on the BLTesterase assay.

This work was supported by grants from the Ligue Nationale Contre le Cancer, the Association pour la Recherche sur le Cancer (C 6227), and the Institut National de la Santé el de la Recherche Médicale (CP 3458).

\section{References}

1. Howard, M., J. Farrar, M. Hilfiker, B. Johnson, K. Takatsu, T. Hamakoa, and W. E. Paul. 1982. Identification of a T cell derived B cell growth factor distinct from interleukin 2. J. Exp. Med. 155:914923.

2. Yokota, T., T. Otsuka, T. Mosmann, J. Banchereau, T. de France, D. Blanchard, J. E. de Vries, and K. I. Arai. 1986. Isolation and characterisation of a human cDNA clone, homologous to mouse BSF-1 which expresses B cells and T cells stimulating activities. Proc. Natl. Acad. Sci. USA. 83:5894-5898.

3. Fernandez-Botran, R., P. H. Krammer, T. Diamantstein, J. W. Uhr, and E. S. Vitteta. 1986. B cell stimulatory factor 1 promotes the growth of helper T cell lines. J. Exp. Med. 164:580-593.

4. Mosmann, T. R., M. W. Bond, R. L. Coffman, J. Ohara, and W. E. Paul. 1986. T cell and mast cell lines respond to B-cell stimulatory factor 1. Proc. Natl. Acad. Sci. USA. 83:5654-5658.

5. Widmer, M. B., R. B. Acres, H. M. Sassenfeld, and K. H. Grabstein. 1987. Regulation of cytolytic cell population from human peripheral blood by B cell stimulatory factor 1 (Interleukin 4). J. Exp. Med. 166:1447-1455.

6. Mulé, J. J., C. A. Smith, and S. A. Rosenberg. 1987. Interleukin 4 can mediate the induction of lymphokine-activated killer activity directed against fresh tumor cells. J. Exp. Med. 166:792-797.

7. Spitz, H., H. Yssel, X. Paliard, R. Kastelein, C. Figdor, and J. de Vries. 1988. IL-4 inhibits IL-2 mediated induction of lymphokine activated killer cells but not the generation of antigen specific cytotoxic T lymphocytes in mixed lymphocyte culture. J. Immunol. 141:29-36.

8. Mulé, J. J., J. A. Krosnick, and S. A. Rosenberg. 1989. IL-4 regulation of murine lymphokine activated killer activity in vitro: effects on the IL-2 induced expansion, cytotoxicity, and phenotype of lymphokine-activated killer effectors. J. Immunol. 142:726-733.
9. Kawakami, Y., M. C. Custer, S. A. Rosenberg, and M. T. Lotze. 1989. IL -4 regulates interleukin 2 induction of lymphokine activated killer activity from human lymphocytes. J. Immunol. 142:3452-3461.

10. Blay, J.-Y., D. Branellec, E. Robinet, F. Gay, and S. Chouaib. 1989. Functional interactions between IL-2, IL-4 and TNF for LAK generation. J. Clin. Lab. Anal. 3:167-171.

11. Smith, J. W., A. L. Steiner, and C. W. Parker. 1971. Modulation of inflammation and immunity by cAMP. J. Clin. Invest. 50:442-447.

12. Bourne, H. R., L. M. Lichtenstein, K. L. Melmon, C. S. Henney, Y. Weinstein, and G. M. Shearer. 1974. Human lymphocyte metabolism: effect of cyclic and non cyclic nucleotides on stimulation by PHA. Science (Wash. DC). 184:19-22.

13. Kammer, G. M. 1989. The adenylate cyclase-cAMP-protein kinase A pathway and regulation of the immune response. Immunol. Today. 9:222-229.

14. Chouaib, S., R. J. Robb, K. Welte, and B. Dupont. 1987. Analysis of the prostaglandin $\mathrm{E} 2$ effect on $\mathrm{T}$ lymphocyte activation. $J$. Clin. Invest. 80:333-340.

15. Beckner, S. K., and W. L. Farrar. 1988. Potentiation of lymphokine activated killer cell differentiation and lymphocyte proliferation by stimulation of protein kinase $\mathrm{C}$ or inhibition of adenylate cyclase. J. Immunol. 140:208-214.

16. Johnson, K. W., B. H. Davis, and K. A. Smith. 1989. cAMP antagonizes interleukin 2-promoted $\mathrm{T}$ cell cycle progression at a discrete point in early G1. Proc. Natl. Acad. Sci. USA. 85:6072-6076.

17. Pasternak, M. S., and H. N. Eisen. 1985. A novel serine esterase expressed by cytotoxic T lymphocytes. Nature (Lond.). 314:743-745.

18. Manyak, C. L., G. P. Norton, C. G. Lobe, R. C. Bleackley, H. K. Gershenfeld, I. L. Weissman, V. Kumar, N. H. Sigal, and G. C. Koo. 1989. Interleukin 2 induces expression of serine protease enzyme and gene in natural killer and non specific $\mathrm{T}$ killer cells. J. Immunol. 142:3707-3713.

19. Ostergaard, H. L., K. P. Kane, M. F. Mescher, and W. R. Clark 1987. Cytotoxic $T$ lymphocyte mediated lysis without release of serine esterase. Nature (Lond.). 330:71-72.

20. Trenn, G., H. Takayama, and M. V. Sitkovsky. 1987. Exocytosis of lytic granules may not be required for target cell lysis by cytolytic T lymphocytes. Nature (Lond.). 330:72-74.

21. Chouaib, S., J. Bertoglio, J. Y. Blay, C. Marchiol, and D. Fradelizi. 1988. Generation of lymphokine activated killer cells: synergy between TNF and interleukin 2. Proc. Natl. Acad. Sci. USA. 85:6875-6879.

22. Blay, J. Y., J. Bertoglio, D. Fradelizi, and S. Chouaib. 1989. Functional interactions of IL-2 and TNF in the differentiation of LGL into LAK effectors. Int. J. Cancer. 44:598-604.

23. White, B. A., and F. C. Bancroft. 1982. Cytoplasmic dot hybridization. J. Biol. Chem. 257:8569-8571.

24. Thomas, P. S. 1980. Hybridization of denatured RNA and small DNA fragments transfered to nitrocellulose. Proc. Natl. Acad. Sci. USA. 77:5201-5204.

25. Degliantoni, G., M. Murphy, M. Kobayashi, M. K. Francis, B. Perrussia, and G. Trinchieri. 1985. Natural killer cell derived hematopoietic colony inhibiting activity and NK cytotoxic factor: relationship with tumor necrosis factor and synergism with immune interferon. $J$. Exp. Med. 162:1512-1530.

26. Nishimura, T., S. J. Burakoff, and S. H. Hermann. 1989. Inhibition of lymphokine activated killer cell mediated cytotoxicity by phorbol ester. J. Immunol. 142:2155-2161.

27. Justement, L., Z. Chen, L. Harris, J. Ransom, V. Sandoval, C. Smith, D. Rennick, N. Roehm, and J. Cambier. 1986. BSF-1 induces membrane protein phosphorylation but not phosphoinositide metabolism, $\mathrm{Ca}^{++}$mobilization, protein kinase $\mathrm{C}$ translocation or membrane depolarisation in resting murine B lymphocytes. J. Immunol. 137:3664-3673.

28. Hart, P. R., G. F. Vitti, D. R. Burgess, G. A. Whitty, D. S. Picolli, and J. A. Hamilton. Potential antiinflammatory effects of IL-4: suppression of human TNF alpha, interleukin 1 and prostaglandin E2. 1989. Proc. Natl. Acad. Sci. USA. 86:3803-3807. 